\title{
Immigration of Foreigners, World Environment and the Nepal Context
}

\author{
Dipak Kaphle1, Dinesh Panthi2 ${ }^{*}$, Chet Raj Bhatta ${ }^{3}$ \\ ${ }^{1}$ Research Centre, Nepal Sanskrit University, Kathmandu, Nepal \\ ${ }^{2}$ Department of Mathematics, Valmeeki Campus, Nepal Sanskrit University, Kathmandu, Nepal \\ ${ }^{3}$ Central Department of Mathematics, Tribhuvan University, Kirtipur, Nepal \\ Email: dktdip@gmail.com, *panthid06@gmail.com
}

How to cite this paper: Kaphle, D., Panthi, D., \& Bhatta, C. R. (2020). Immigration of Foreigners, World Environment and the Nepal Context. Open Journal of Social Sciences, 8, 106-116.

https://doi.org/10.4236/jss.2020.810008

Received: August 27, 2020

Accepted: October 17, 2020

Published: October 20, 2020

Copyright (c) 2020 by author(s) and Scientific Research Publishing Inc. This work is licensed under the Creative Commons Attribution International License (CC BY 4.0).

http://creativecommons.org/licenses/by/4.0/

\begin{abstract}
In different countries of the world, the state administrators have identified the country by preparing the borders of their country. It is found that all the countries have done the work of keeping officials records of people coming and going from one country to another. People who travel to different countries of the world come mainly as tourism, business, labor, diplomatic, government work, family relation and refugees, etc. Under normal circumstances, about 15 to 18 percent of the world's population travels to another country each year. In this article, we investigate the immigration causes, their effects on environment in the context of Nepal.
\end{abstract}

\section{Keywords}

Immigration, Tourism, Million, Foreigners, Population, Remittance, Migration, Traffic

\section{Introduction}

The territory under the control of a government within a certain geographical area introduces the geographical identity of the country. In order to demarcate a country from another country, the boundaries established by drawing special lines between two countries therefore separate the countries from each other. Determined from various treaties, agreements, understandings, etc., using various signs, political maps, charts, physical boundary pillars, walls, fences, oceans, rivers, canals, roads, forests, piles of stones, etc. and using artificial signs to maintain artificial separation, the practice of running the state by maintaining the country, state, union, city, district, region, etc. has been going on for a long time. The boundaries of a country are generally considered to be directly below 
the surface of the earth to the center of the earth and straight up to an infinite distance in the sky.

Along with the provision of no movement of people living in other border areas without the administrative permission of the people living within the administrative boundaries of the country, various countries established in the world have been arranging the movement of foreigners in their countries by developing a system of record keeping of people moving in their territory. The movement of people from one country to another is mainly in the form of tourism, business, diplomatic, religious and refugee. This article analyzes the movement of foreigners in the world through statistical methods. The result is analyzed using data published by the organizations that keep records of foreign traffic (Immigration) as a source. The themes presented in this article illustrate the analysis of the movement of foreigners and are useful in the context of Nepal as well.

\section{Tourist Immigration}

The act of legally moving people from one country to another and spending some time in that country is part of tourism. The formal beginning of world tourism for recreation, relaxation and pleasure seems to have come from Western Europe in the 17th century. With the establishment of states and countries, the concept of tourism seems to be evolved from people moving from one country to another to meet their various requirements. For observation, amusement, business, study, research of the cultural, religion, man-made monuments, parks and the natural environment of a country, people participate in tourism activities by arranging personal and institutional transportation.

Tourism, which is an important element of globalization, is developing as the basis of economic prosperity of every country. According to worldometers information Until 18 April 2020 or 2077/1/6 B.S. (Bikram Sambat-Bikram's calender) at 12:30 pm., the world's population is about 7,778,549,740 (Seven billion seven hundred seventy-eight million five hundred forty-nine thousand seven hundred forty). (Worldometers, 2020). About 15 to 18 percent of the world's population travels internationally each year (International Migration Report, 2015). The United Nations World Tourism Organization (UNWTO) has been publishing the number of foreigners visiting the inter-countries and continents every year. According to the data available on the organization's website, in 2018, about 1,401,000,000 (one billion and forty million) people in the world have travelled abroad. In 1950, 25 million (1 million equals 10 lakhs) people traveled abroad, and 20 years later, in 1970, 166 million people traveled abroad. Similarly, in 2018, 1.4 billion (100 million equivalents to 1 billion) people have migrated abroad. According to the World Tourism Organization, the top ten foreign destinations in the world account for more than 50 percent of world tourism. In this context, analyzing the statistics of the last two years, it is seen that the number of foreigners visiting these countries is as follows. 
According to the presented Table 1 and Figure 1 the number of foreigners in the main destination country has increased annually. Comparison of top countries in terms of foreigners' visits. Turkey being highest in terms of increased ratio between two successive years; followed by Thailand, Italy and others.

In 2017, about 62.8 million people visited African countries, including Morocco, Egypt, South Africa, Tunisia, Algeria, Zimbabwe, Ivory Coast, Botswana, Namibia and Mozambique. Despite an increase of about 8.5 percent compared to 2016, foreign traffic in the African region appears to be relatively low.

In 2018 AD 215.7 million foreigners visited The United States of America, Mexico, Canada, Argentina, Brazil, the Dominican Republic, Chile, Cuba, Peru, Colombia and other countries of American continent. This is an increase of about 2.3 percent from 2017, which is about 20 percent of world traffic. Similarly, China, Thailand, Japan, Malaysia, India, Vietnam, South Korea, Singapore and other Asia-Pacific countries and places in 2018, about 347 million foreigners

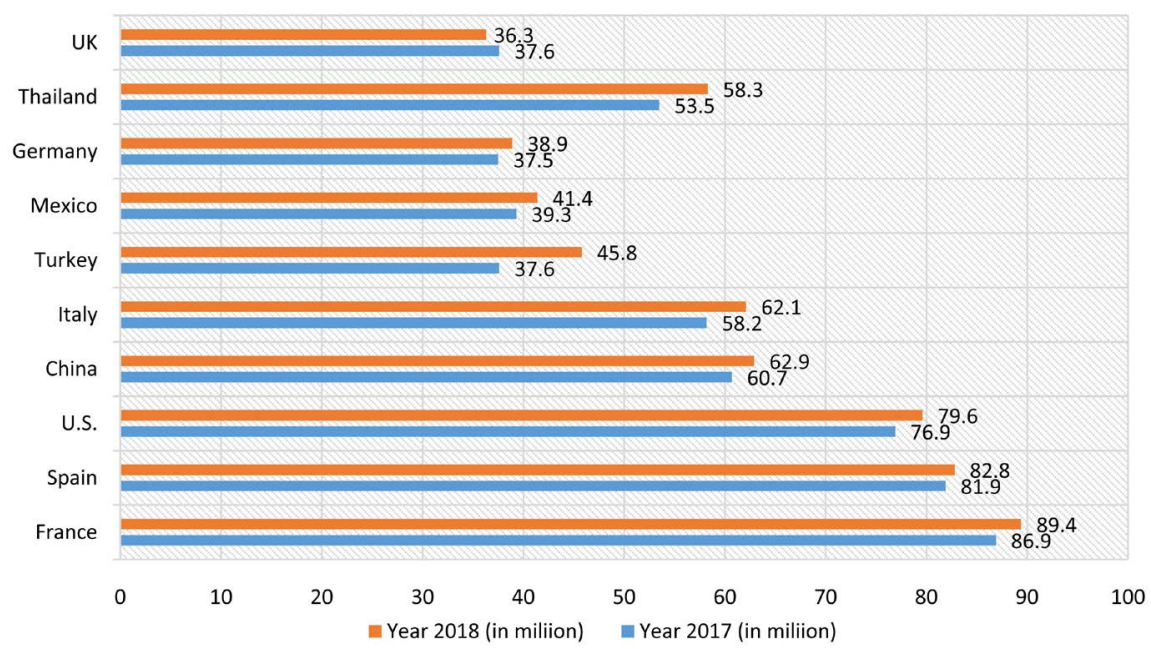

Figure 1. Foreigners' number in destination countries (in million).

Table 1. The presence of foreigners in the main destination countries of foreign travel.

\begin{tabular}{ccccc}
\hline S. N. & Name of Country & Year 2017 (in miliion) & Year 2018 (in miliion) & Percentage change \\
\hline 1. & France & 86.9 & 89.4 & 2.9 \\
2. & Spain & 81.9 & 82.8 & 1.1 \\
3. & U.S. & 76.9 & 79.6 & 3.5 \\
4. & China & 60.7 & 62.9 & 3.6 \\
5. & Italy & 58.2 & 62.1 & 6.7 \\
6. & Turkey & 37.6 & 45.8 & 21.7 \\
7. & Mexico & 39.3 & 41.4 & 5.5 \\
8. & Germany & 37.5 & 38.9 & 3.8 \\
9. & Thailand & 53.5 & 58.3 & 7.9 \\
10 & UK & 37.6 & 36.3 & -3.5 \\
\hline
\end{tabular}

Source: UNWTO. 
have visited. The fact that the number of traffic has increased by 7.3 percent as compared to 2017 is also a big part of the global immigration.

Europe seems to account for a large share of foreign traffic. Around 710 million foreigners visited European countries in 2018, including France, Spain, Italy, Turkey, Germany, the United Kingdom, Austria, Greece, Russia and Portugal. Europe, with 5.5 percent more tourist traffic than in year 2017, accounts for more than half of the world's traffic. Similarly, in Saudi Arabia, United Arab Emirates, Oman, Qatar and other middle-east countries in sum, about 57.7 million foreigners are observed in year 2017. The data confirms that the movement of foreigners is increasing even in Arabic region, which has increased by about 4.1 percent as compared to 2016. Figure 1 shows the movement of foreigners in different countries, which reflects that situation of the top 10 countries in the world where foreigners travel.

The global attractions of foreign tourists include the culture, art, cuisine or taste and dishes of food, infrastructure, geography, historical events, natural structures and places for trade and shopping (Nepal tourism statistics, 2018). The most visited destinations in the world are Niagara Falls between the United States and Canada, the Pyramids of Egypt, the Great Wall of China, the Eiffel Tower of France, the Acropolis of Athens, Greece, Brazil, the United Kingdom, Peru and Iceland (International Migration Statistics, 2016). The World Tourism Organization (UNWTO) has released the following statistics on the number of foreigners visiting the following places in the world in 2018.

It is seen that the movement of foreigners from one country to another is mainly based on the convenience of access to the destination country, the accommodation facilities, suitability to carry out activities as per one's wish, other facilities, etc. People travel to other countries for entertainment, institutional work, understanding of culture, sports, religion, labor and business, and treatment and to involve in adventure activities. It seems that the destination country gets huge economic benefits from the expenses incurred by the people and other administrative tasks while traveling in this way. The income earned by these countries on the basis of their main destination for foreign travel is evident from Table 2 and Figure 2 presented.

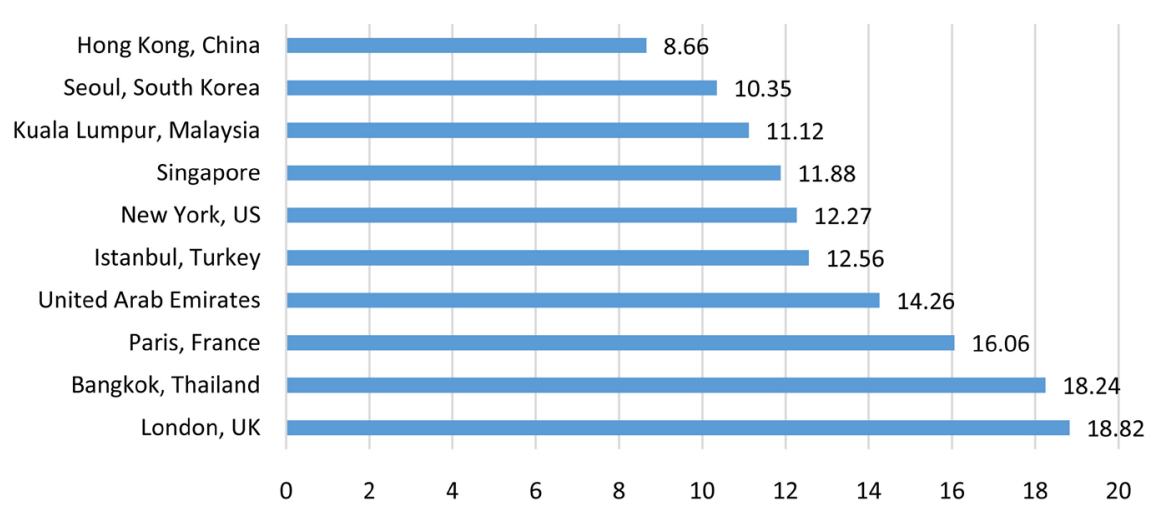

Figure 2. Income in million (In USD) of various destination. 
Table 2. World's best destinations and tourist income.

\begin{tabular}{ccc}
\hline S. N. & Destination & Income in million (American Dollars) \\
\hline 1. & London, UK & 18.82 \\
2. & Bangkok, Thailand & 18.24 \\
23. & Paris, France & 16.06 \\
4. & United Arab Emirates & 14.26 \\
5. & Istanbul, Turkey & 12.56 \\
6. & New York, US & 12.27 \\
7. & Singapore & 11.88 \\
8. & Kuala Lumpur, Malaysia & 11.12 \\
9. & Seoul, South Korea & 10.35 \\
10. & Hong Kong & 8.66 \\
\hline
\end{tabular}

Source: UNWTO.

Tourism accounts for about 3.9 percent of the world's gross domestic product (GDP). In 2018, the sector generated about 8.8 trillion in global revenue and created about 319 million jobs. About 10.4 percent of the world's economic activity comes from managing the movement of foreigners. Table 3 is the list of the top 10 countries in the world earning high income from foreign traffic management in 2018 (Figure 3).

The situation of other countries can also be reviewed based on Figure 4 which shows the increasing income of 10 countries of the world which have high income due to the movement of foreigners. Nepal is also identified as an important tourist destination place given its religious heritage and landscapes suitable for adventurous activities (Nepal Tourism Statistics, 2017). Both Hindu and Buddhist pilgrimage can find places like Buddha's born place, Pashupatinath, etc. With, Mount Everest (Sagarmatha), the highest peak in the world, Nepal is well known for mountaineering, rock climbing, trekking, adventure activities with favorable climate, diverse in culture, cultural activities, art, festivals, processions and bio-diversity of wild animals, birds and butterflies, adventurous sports activities, various fresh water lakes, rivers, waterfalls, etc. According to the Travel and Tourism Competitiveness index published in 2019, Nepal is ranked $102^{\text {nd }}$ out of 140 countries studied. Tourism activities in Nepal have created about 427,000 (four hundred and twenty-seven thousand) jobs in year 2018, which is about 3 percent of the total employment in Nepal. Tourism in Nepal accounted for 3.6 percent of GDP in year 2018, while tourism accounted for 7.9 percent of Nepal's total economic activity.

\section{Labor Immigration}

Labor migration is the main area of international migration of people (Gills \& Ira, 2010). The movement of bulk population from one country to another, for 


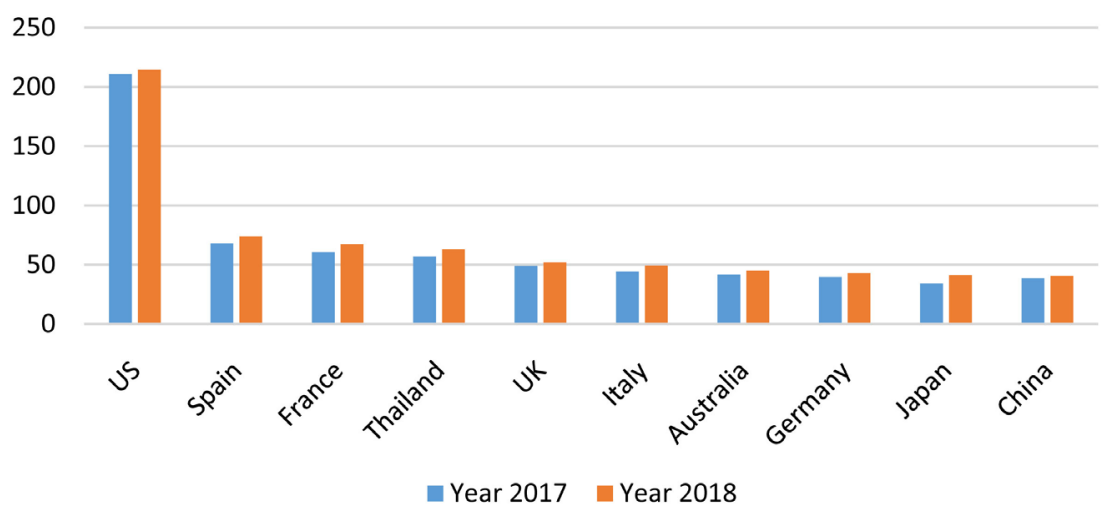

Figure 3. Top 10 countries income from tourist management.

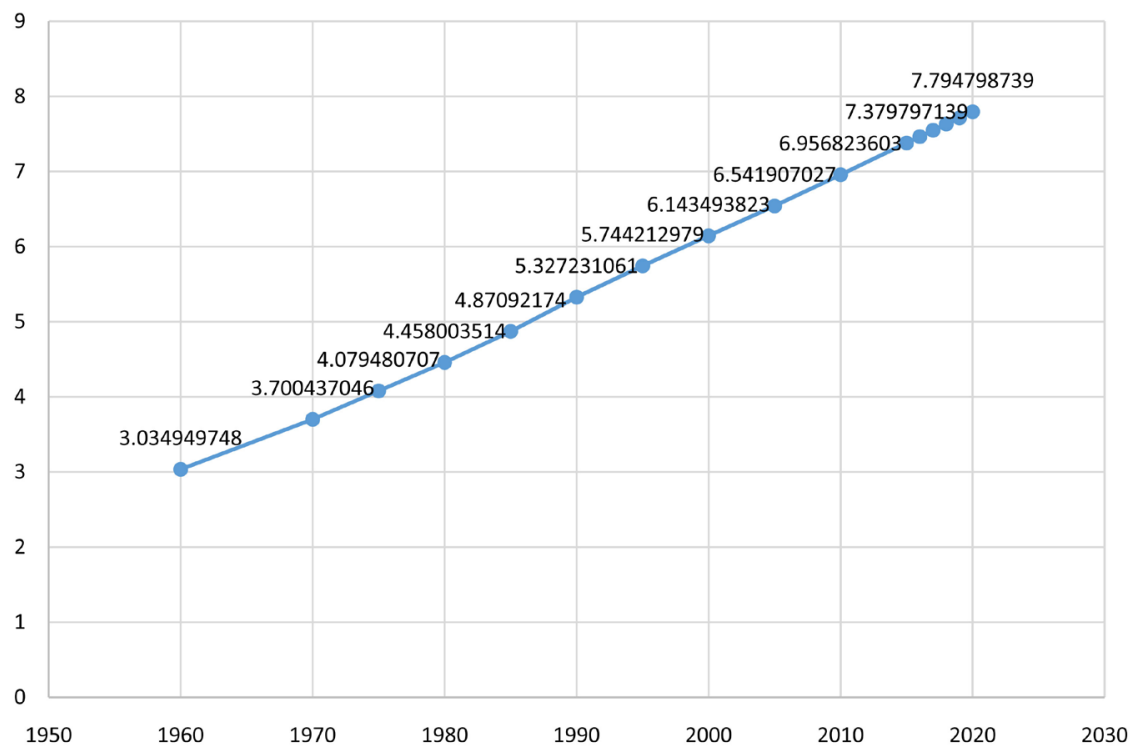

Figure 4. Growing world population trend.

Table 3. Top ten countries earning high income from foreign traffic management.

\begin{tabular}{ccccc}
\hline S. N. & $\begin{array}{c}\text { Name } \\
\text { of country }\end{array}$ & $\begin{array}{c}\text { Year 2017 } \\
\text { (In Billion Dollars) }\end{array}$ & $\begin{array}{c}\text { Year 2018 } \\
\text { (In Billion Dollars) }\end{array}$ & $\begin{array}{c}\text { Percentage } \\
\text { Change }\end{array}$ \\
\hline 1. & US & 210.7 & 214.5 & 1.8 \\
2. & Spain & 68.1 & 73.8 & 8.4 \\
3. & France & 60.7 & 67.3 & 10.9 \\
4. & Thailand & 56.9 & 63.0 & 10.7 \\
5. & UK & 49.0 & 51.9 & 5.9 \\
6. & Italy & 44.2 & 49.3 & 11.5 \\
7. & Australia & 41.7 & 45.0 & 7.9 \\
8. & Germany & 39.8 & 43.0 & 8.0 \\
9. & Japan & 34.1 & 41.1 & 20.5 \\
10. & China & 38.6 & 40.4 & 4.7 \\
\hline
\end{tabular}

Source: UNWTO. 
employment has been seen. About half of the world's population can work and are in active age, so this labor force is either consumed in their own country or in goes to other countries for better employment. To make living better from the income earned and sell their skills and abilities, labor force tends to go abroad. As the world's population continues to grow, labor and employment are needed for human management. The world's population indicators are as follows presented in Table 4 and the graphic representation are shown as follows.

The comparative distribution of population status can be shown with the following graph.

Analyzing the world's population growth rate, Fertility rate, population density and the statistical rate of people living in urban areas in the last 60 years according to Table 4 and Figure 5 shows that the world population indicators are changing.

The world's population grew from about 3.03 billion in 1960 to about 6.95 billion 50 years later. The population, which has almost doubled in 50 years, is projected to reach 8 billion by 2025 and 9 billion by 2030. With a population of over one billion, China and India alone account for about 36 percent of the world's population. The 20 most populous countries in the world are China, India, USA, Indonesia, Pakistan, Brazil, Nigeria, Bangladesh, Russia, Mexico, Japan, Ethiopia, Philippines, Egypt, Vietnam, Congo, Turkey, Germany, Iran and Thailand. These 20 countries account for more than half the world's population.

Table 4. World population status.

\begin{tabular}{|c|c|c|c|c|c|c|}
\hline S. N. & Year & Population & $\begin{array}{c}\text { Growth } \\
\text { rate }\end{array}$ & $\begin{array}{l}\text { Fertility } \\
\text { rate }\end{array}$ & $\begin{array}{c}\text { Population } \\
\text { density }\end{array}$ & $\begin{array}{c}\text { Urban } \\
\text { population }\end{array}$ \\
\hline 1. & 1960 & $3,034,949,748$ & 1.86 & - & 20 & 34 \\
\hline 2. & 1970 & $3,700,437,046$ & 2.07 & 4.39 & 25 & 36.6 \\
\hline 3. & 1975 & $4,079,480,707$ & 1.97 & 4.47 & 26 & 37.7 \\
\hline 4. & 1980 & $4,458,003,514$ & 1.79 & 3.86 & 30 & 39.3 \\
\hline 5. & 1985 & $4,870,921,740$ & 1.79 & 3.59 & 33 & 41.2 \\
\hline 6. & 1990 & $5,327,231,061$ & 1.81 & 3.44 & 36 & 43.0 \\
\hline 7. & 1995 & $5,744,212,979$ & 1.52 & 3.01 & 39 & 44.8 \\
\hline 8. & 2000 & $6,143,493,823$ & 1.35 & 2.78 & 41 & 46.7 \\
\hline 9. & 2005 & $6,541,907,027$ & 1.26 & 2.65 & 44 & 49.2 \\
\hline 10. & 2010 & $6,956,823,603$ & 1.24 & 2.58 & 47 & 51.7 \\
\hline 11. & 2015 & $7,379,797,139$ & 1.16 & 2.52 & 50 & 54.0 \\
\hline 12. & 2016 & $7,464,022,049$ & 1.14 & 2.51 & 50 & 54.4 \\
\hline 13. & 2017 & $7,547,858,925$ & 1.12 & 2.51 & 51 & 54.9 \\
\hline 14. & 2018 & $7,631,091,040$ & 1.10 & 2.51 & 51 & 55.3 \\
\hline 15. & 2019 & $7,713,468,100$ & 1.08 & 2.51 & 52 & 55.7 \\
\hline 16. & 2020 & $7,794,798,739$ & 1.05 & 2.47 & 52 & 56.2 \\
\hline
\end{tabular}

Source: https://www.worldometers.info/. 


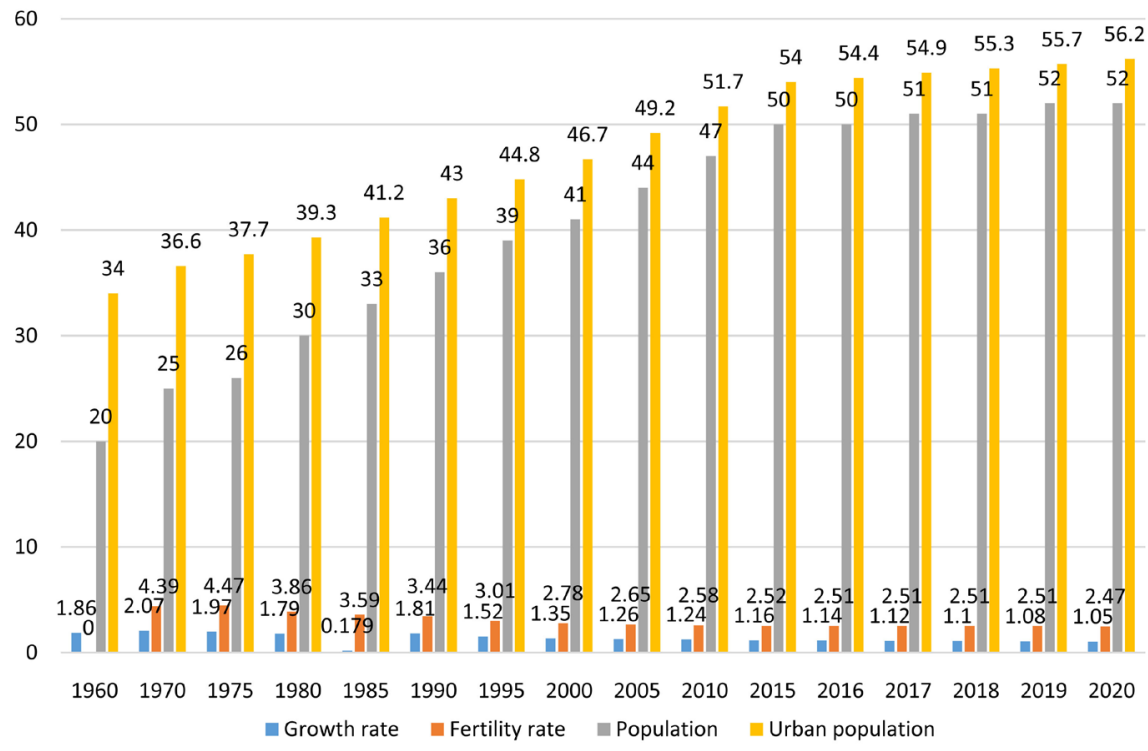

Figure 5. Comparative distribution of population status.

Half of the world's population is in some form of employment. About 3.5 billion people are employed at home or abroad. People from China and India, which have the largest population in the world, seem to have gone to many other countries for employment. Countries with a per capita income above 12,446 dollars are listed as high-income by the World Bank. Eighty-one countries receive about 68 percent of global remittances from foreign employment. About 58 upper-middle-income countries, with per capita incomes ranging from 4038 to 12,445 dollars have about 18 percent of remittances flow from labor migration. Similarly, 53 low-middle-income countries with a per capita income of 1026 to 4037 dollars' account for 10 percent and other countries with a per capita income of less than 1025 account for about 4 percent of remittances from labor migration.

In 2017, there were 164 million people in the world in labor migration. According to figures published by the International Labor Organization (ILO), 96 million men and 68 million women are in international labor migration. Eighty-seven percent of those in labor immigration are between the ages of 25 and 64. In 2017, there were 91 countries receiving more than 10 percent of the country's gross domestic product through remittances, while all the countries in the world have received some form of resources through remittances. India receives about 12 percent of the world's remittances. About 35 million Indian citizens are in various countries of the world as labor migrants. Nepal is also in the list of 10 countries in the world receiving the most remittances, which is presented as follows (Table 5).

About 30 percent of Nepal's GDP (Gross Domestic Product) comes from remittances. The main countries from where remittances in flow to Nepal are gulf countries and Malaysia, similarly the United state of America, Russia, Saudi Arabia, Switzerland, Italy, Canada, France, Spain, etc. countries are among the 
Table 5. Countries receiving the highest remittances in the world and income status.

\begin{tabular}{|c|c|c|c|c|c|c|c|}
\hline \multirow{2}{*}{ S. N. } & \multirow{2}{*}{$\begin{array}{l}\text { Name of } \\
\text { countries }\end{array}$} & \multicolumn{6}{|c|}{ Remittance in American dollars } \\
\hline & & 2012 & 2013 & 2014 & 2015 & 2016 & 2017 \\
\hline 1 & India & 68.82 & 69.9 & 70.97 & 72.20 & 62.7 & 69 \\
\hline 2 & China & 57.99 & 59.49 & 61.42 & 63.90 & 61.0 & 64 \\
\hline 3 & Philippines & 24.61 & 26.70 & 27.90 & 29.80 & 29.9 & 33 \\
\hline 4 & Mexico & 23.37 & 23.02 & 24.50 & 25.70 & 28.5 & 31 \\
\hline 5 & Nigeria & 20.63 & 20.89 & 20.88 & 20.89 & 19 & 22 \\
\hline 6 & Pakistan & 14.01 & 14.63 & 17.89 & 20.10 & 19.8 & 20 \\
\hline 7 & Egypt & 19.24 & 17.83 & 19.83 & 20.4 & 16.6 & 20 \\
\hline 8 & Vietnam & 10.0 & 11.0 & 11.8 & 12.3 & 13.4 & 14 \\
\hline 9 & Bangladesh & 14.24 & 13.86 & 15.1 & 15.8 & 13.7 & 13 \\
\hline 10 & Nepal & 5.88 & 6.01 & 5.29 & 5.8 & 6.4 & 6.68 \\
\hline
\end{tabular}

Source: Wikipedia (25 April 2020).

major remittance sending countries in the world. In the age of globalization and liberalization, labor migration is the main area of migration in the world, all countries seem to have been involved in one way or another.

\section{Worldwide Migration Indicators}

Due to conflict, poverty, inequality and lack of employment in their own country, people move from where they live. Migration within one's own country is of an internal nature, while permanent or temporary migration from one country to another is international migration which can be observed as global phenomenon (Mortin, 2005). The number of people who migrated worldwide increased from 173 million in 2000 to 244 million in 2015. The International Organization for Migration's (IOM) Global Migration Indicator, shows the status of migratory areas in relation to international migration areas, which are growing at a rate of about two to three percent annually (Global migration indicator, 2018). In 2017, 258 million people worldwide migrated internationally. About 3.4 percent of the world's population migrated internationally, with 150.3 million people in labor migration. Of those who moved, 4.8 million went to study. 25.4 million were living as refugees. Out of the international migrants, 14 percent were children and 48.8 percent were women. In 2017, 466 billion dollars was remitted from global migration. In 2017, the situation of world migration was as follows (Table 6).

Of the world's migrants, 14 percent are under the age of 20 and 48 percent are women. About 23 percent of the world's migrants migrate to Europe, 25 percent to North America, 14 percent to Asia, 3 percent to Latin America, 5.5 percent to Africa, 7.5 percent to Asia Pacific and 12 percent to Arab states). The number of people going to study in international immigration is also increasing (Chatterjee, 2018). So this kind of multifaceted international migration is mainly due to 
Table 6. World migration status 2017.

\begin{tabular}{cccc}
\hline S. N. & Migration Area & $\begin{array}{c}\text { In flux of emigrants } \\
\text { (in million) }\end{array}$ & $\begin{array}{c}\text { Migrated } \\
\text { (in million) }\end{array}$ \\
\hline 1 & Europe & 78 & 64 \\
2 & Asia & 80 & 110 \\
3 & North America & 58 & 5 \\
4 & Africa & 25 & 5 \\
5 & Latin America and Caribbean & 10 & 39 \\
6 & Bosnia & 8 & 2 \\
& Total & 259 & 258 \\
\hline
\end{tabular}

Source: www.migrationdata portal.org (25 April 2020).

either internal conflict or economic opportunity which results in the form of demographic displacement, irregular movement from one country to another, refugees, disappearances, off the record illegal migration (Stiglitz, 2002).

It is seen that Nepalese go to more than 150 countries of the world for various purposes (Reports on Nepal's foreign affairs, 2017-2018). Although immigration relations, which were initially only with India, are now increasing in other countries. Still it is about 35 percent accounts migration to India mainly for job opportunities or for other reasons. With the globalization of markets and work force, about 6 million people are leaving Nepal and about 1 million foreigners are coming to Nepal.

\section{Conclusion}

Along with the global movement of people, labor, technology, remittance, enthusiasm, encouragement have added new impetus to world development, while social distortions are also increasing due to conflict, family separation and family distance. In the wave of globalization, the country has moved ahead with the agenda of sustainable development by making the global movement of people more systematic, including the management of immigration in the world development.

\section{Conflicts of Interest}

The authors declare no conflicts of interest regarding the publication of this article.

\section{References}

https://www.worldometers.info/

Chatterjee, A. (2018). International Relations Today Concepts and Applications. Pearson India Education Service Pvt. Ltd., India.

Gills, E., \& Ira, G. N (2010). Migration and Culture. Discussion Paper No 5123, Germany. https://doi.org/10.1108/S1574-8715(2010)8 
Global Migration Indicators (2018). International Organization for Migration.

International Migration Report (2015). New York, United Nations: Department of Economics and Social Affairs.

International Migration Statistics (2016). International Organization for Migration (IOM).

Mortin, S. (2005). The Legal and Normative Framework of International Migration. Institute for the study of international Migration Georgetown University, Georgetown.

Nepal Tourism Statistics (2017). Kathmandu: Ministry of Culture, Tourism and Civil Aviation.

Nepal Tourism Statistics (2018). Kathmandu: Ministry of culture, Tourism and Civil Aviation.

Report on Nepal's Foreign Affairs (2017-2018). Government of Nepal, Kathmandu: Ministry of Foreign affairs.

Stiglitz, J. (2002). Globalization and Its Discontent. New Delhi: A penguin Book. 